\title{
Small Bowel Obstruction by Broad Ligament Hernia: Three Case Reports, Management and Outcomes
}

\author{
Oclusão do Intestino Delgado por Hérnia do Ligamento \\ Largo do Útero: Três Casos Clínicos, Tratamento e \\ Resultados
}

Manuela Graça FERNANDES ${ }^{1}$, Ana Rita LOUREIRO'1, Maria João OBRIST ${ }^{1}$, César PRUDENTE1 Acta Med Port 2019 Mar;32(3):240-243 - https://doi.org/10.20344/amp.10951

\section{ABSTRACT}

Internal hernias are a rare cause of bowel obstruction (1\%) and can be caused by broad ligament defects in $4 \%$ to $7 \%$ of the cases. These defects may be congenital or acquired and are classified according to its anatomical location. This paper reports three cases of small bowel obstruction by broad ligament hernia. The patients, three women aged from 35 to 51 years old, were admitted to the emergency department with small bowel obstruction. An exploratory laparotomy was performed during which an internal hernia through a broad ligament defect was identified. In all cases the hernia content was reduced and the defect closed. One of the patients required a segmental enterectomy. All patients had a favorable outcome. This paper aims to raise awareness about the broad ligament hernia as a cause of bowel obstruction, namely in middle-aged women with no surgical history.

Keywords: Broad Ligament; Hernia; Intestinal Obstruction

\section{RESUMO}

As hérnias internas são uma causa rara de oclusão intestinal (1\%) e podem ser causadas por anomalias do ligamento largo do útero em $4 \%$ a $7 \%$ dos casos. Estas anomalias podem ser congénitas ou adquiridas e são classificadas de acordo com a sua localização anatómica. Descrevem-se três casos clínicos de oclusão de intestino delgado por hérnia do ligamento largo do útero. Três mulheres com idades entre os 35 e 51 anos recorreram ao serviço de urgência com quadro de oclusão intestinal. No decurso de laparotomia exploradora foi identificada uma hérnia interna através do ligamento largo do útero. Em todos os casos o conteúdo herniado foi reduzido e o orifício encerrado. Uma das doentes necessitou de enterectomia segmentar. Todas as doentes evoluíram favoravelmente. Este trabalho pretende alertar para o diagnóstico de hérnia do ligamento largo do útero como causa de oclusão intestinal, principalmente em mulheres de meia idade, sem antecedentes cirúrgicos.

Palavras-chave: Hérnia; Ligamento Largo; Obstrução Intestinal

\section{INTRODUCTION}

Internal hernias are a rare cause of bowel obstruction $(1 \%)^{1-3}$ Even rarer, is bowel obstruction caused by herniation through a broad ligament defect. ${ }^{1,2,4}$ These defects were first reported in 1861 by Quain. ${ }^{2,3}$

Broad ligament defects may be congenital or acquired. The former results from a spontaneous rupture of cystic structures in the broad ligament. These cystic structures are thought to be congenital remnants of the mesonephric or mullerian ducts. The latter, may be secondary to abdominal surgery, pelvic inflammatory disease (PID) or childbirth trauma. $1,3,4$

Although small bowel herniation through this defect is the most common complication, there are reports of herniations of other structures like the ureter or the ovary. ${ }^{4}$

This paper details three cases of small bowel obstruction caused by a broad ligament hernia. All cases were successfully treated by surgery.

\section{CASE REPORT}

Case 1: A 35-year-old woman, gravida 1 para 1 (eutocic), without previous history of abdominal surgery or PID, presented at the emergency department with pain in the left hypochondrium, referred pain to the dorsal region, nausea, and vomiting. These symptoms had two days of evolution. In the initial physical examination, the patient was stable, afebrile, and had diminished bowel sounds. The abdomen was soft and depressible, exhibiting pain in the left hypochondrium, without tenderness. Blood analysis presented normal values except for slightly increased inflammatory markers (Table 1). An upright abdominal radiography showed multiple air-fluid levels in the small bowel loops. A computed tomography revealed a distention of the small bowel sparing the duodenum and the terminal ileum with no identifiable cause (Fig. 1). Despite the fluid therapy and nasogastric tube drainage, the clinical course progressed to abdominal distention and tenderness, which prompted surgical treatment. An exploratory laparotomy revealed a small bowel hernia through a defect on the left broad ligament. The right broad ligament also presented a punctiform defect. The herniated bowel was reduced, and both defects sutured to prevent recurrences (Fig. 2). Apart from postoperative ileus, the patient presented no other complication and was discharged on the seventh day after surgery.

Case 2: A 43-year-old woman, gravida 0, without a history of abdominal surgery or PID was admitted with abdominal pain associated with nausea, vomiting and constipation

1. Department of Surgery. Centro Hospitalar Tondela-Viseu. Viseu. Portugal.

$\triangle$ Autor correspondente: Manuela Graça Fernandes. manuelamgf@gmail.com

Recebido: 18 de Junho de 2018 - Aceite: 23 de Julho de 2018 | Copyright @ Ordem dos Médicos 2019 
Table 1 - Results of blood tests from the three reported cases

\begin{tabular}{|c|c|c|c|c|}
\hline Test & Case 1 & Case 2 & Case 3 & Reference value \\
\hline Leukocytes & $13.3^{*}$ & $13.3^{*}$ & $20.5^{*}$ & $4.5-11.5 \times 10^{9} / \mathrm{L}$ \\
\hline Neutrophils & $90.1^{*}$ & $81^{*}$ & $84.4^{*}$ & $>75 \%$ \\
\hline Hemoglobin & 13.9 & 16.2 & 13.7 & $12-15 \mathrm{~g} / \mathrm{dL}$ \\
\hline Platelets & 309 & 240 & 269 & $150-450 \times 10^{9} / \mathrm{L}$ \\
\hline Urea & 67 & 45 & 54 & $13-42 \mathrm{mg} / \mathrm{dL}$ \\
\hline Creatinine & 1.3 & 0.8 & 0.6 & $0.5-1.2 \mathrm{mg} / \mathrm{dL}$ \\
\hline Sodium & 139 & 135 & 140 & $136-145 \mathrm{mEq} / \mathrm{L}$ \\
\hline Potassium & 4.9 & 3,9 & 4.2 & $3.4-4.5 \mathrm{mEq} / \mathrm{L}$ \\
\hline C-reactive-protein & $2.06^{*}$ & $4.74^{*}$ & $21.91^{*}$ & $<0.5 \mathrm{mg} / \mathrm{dL}$ \\
\hline
\end{tabular}

${ }^{*}$ Values that differ from reference values

for five days. On examination, the patient was stable and afebrile. The abdomen was distended, tympanized, with decreased peristaltic sounds and diffuse pain on palpation. The pain was more intense in the lower quadrants, with tenderness and rebound tenderness. The blood analysis revealed leukocytosis and high C-reactive-protein (Table 1). The abdominal radiography showed distended small bowel loops with thickened wall and air-fluid levels. The computed tomography also revealed distended small bowel loops and, additionally, suggested an internal hernia on the left inferior quadrant (Fig. 3). The patient underwent exploratory laparotomy, in which a left broad ligament hernia was identified. The herniated bowel was reduced and the broad ligament defect was closed. The postoperative course was uneventful and the patient was discharged on the sixth day after surgery.

Case 3: A 51-year-old woman, gravida 1 para 1 (eutocic), with no previous abdominal surgeries or PID, was observed in the emergency department with diffuse abdominal pain, nausea and vomiting with one week of evolution, and two episodes of diarrhea. The patient was hemodynamically stable, with auricular temperature of $38.2^{\circ} \mathrm{C}$. The abdomen was distended, diffusely painful on palpation, more intense in the lower quadrants, with peritoneal signs. The blood analysis revealed elevated inflammatory parameters (Table 1). A thoracic radiography and abdominal echography
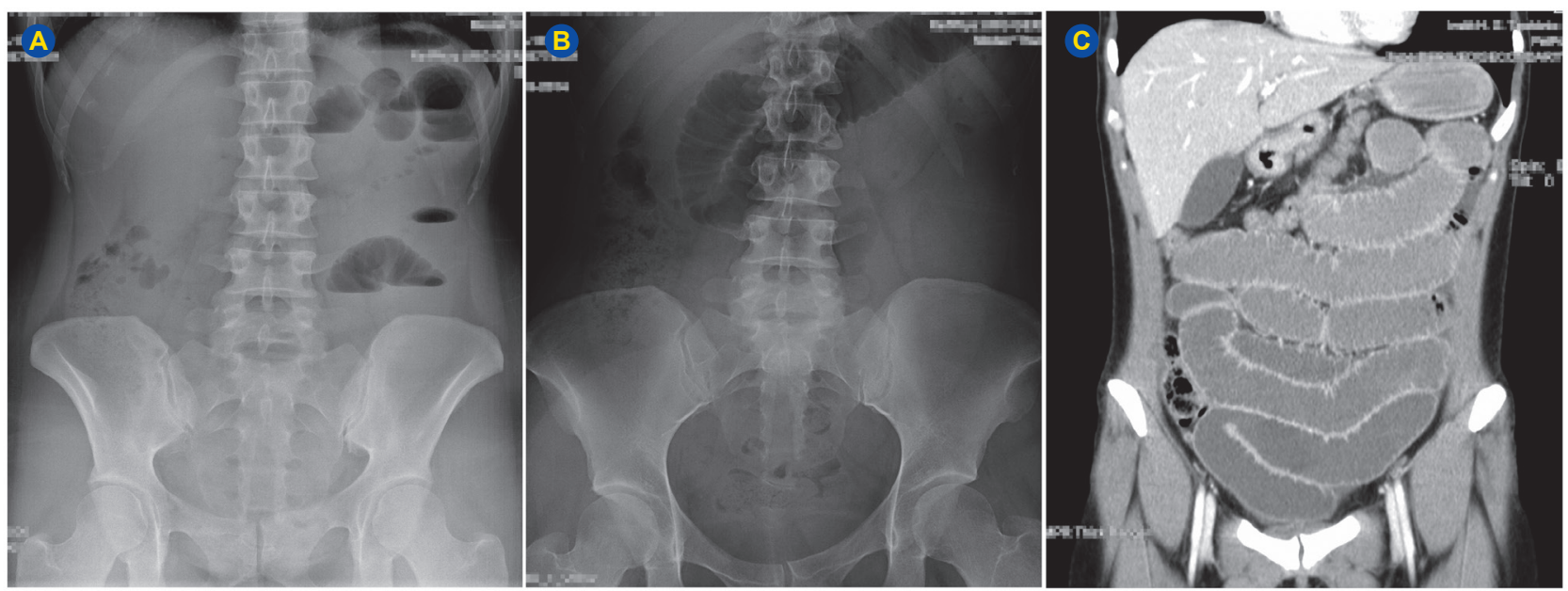

Figure 1 - Abdominal radiographies with multiple air-fluid levels situated in small bowel loops in the left quadrants (A) and distended small bowel loop in epigastric region (B); Computed tomography with marked distended loops and thickened wall (C).
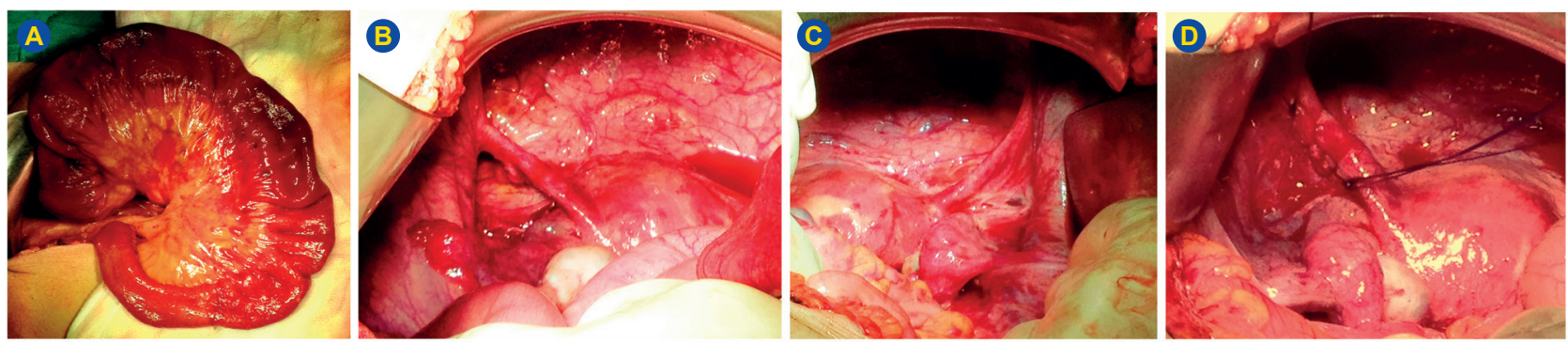

Figure 2 - Reduced intestinal hernia with viability (A); defect on the left broad ligament (B); weakened right broad ligament with a punctiform defect (C); left broad ligament defect sutured (D). 

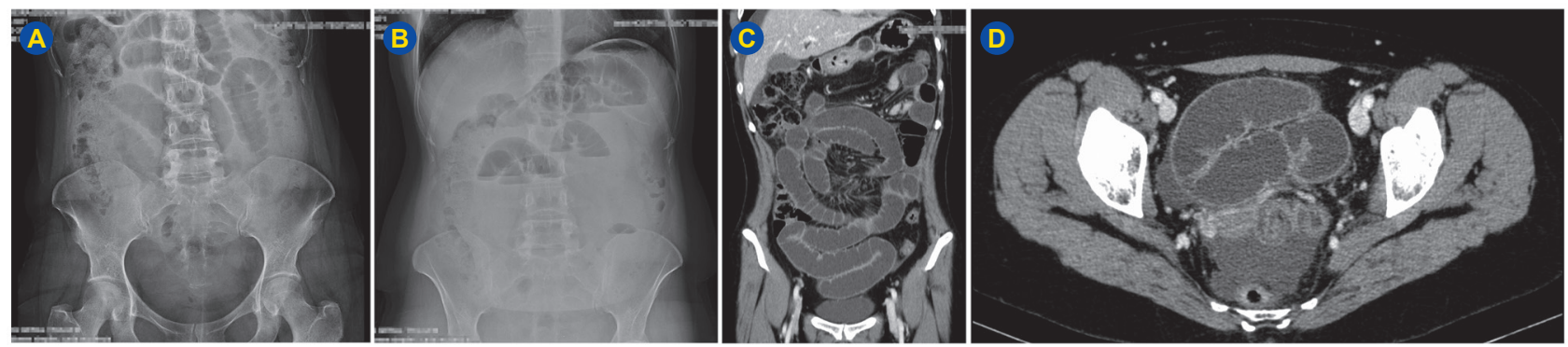

Figure 3 - Abdominal radiographies with distended small bowel loops with thickened wall $(\mathrm{A})$ and multiple air-fluid levels in small bowel loops in the upper quadrants (B); Computed tomography with marked distended small bowel loops with thickened wall (C) and an abrupt change in the size of the ileal loop compatible with internal hernia, visible on the lower left quadrant (D).

revealed a small bowel distention and air-fluid levels (Fig. 4). The patient underwent urgent abdominal laparotomy that revealed a small bowel hernia in a broad ligament defect. The hernia was reduced and the defect of the broad ligament was sutured. As a result of the herniated intestine being necrotic, a segmented enterectomy was performed. The postoperative course was uneventful and the patient was discharged on the seventh day after surgery.

\section{DISCUSSION}

Herniation through a defect in the broad ligament of the uterus is an uncommon cause of bowel obstruction, accounting for $4 \%$ to $7 \%$ of internal hernias. ${ }^{1-4}$ These defects can be classified according to their location in three types: type 1: defect in the broad ligament; type 2: defect in the mesosalpinx and mesovarium; and type 3: defect in the meso-ligamentum teres. ${ }^{1}$ The three patients discussed here, presented a type 1 defect, the most frequent type.

The broad ligament defects may be congenital or secondary to abdominal surgery, pelvic inflammatory disease or childbirth trauma. ${ }^{1,3,4}$ In the first and third cases, the patients had had a child, so the broad ligament defect could be due to trauma during childbirth. In the second case, the patient had no history of childbirth, abdominal surgery or PID, so the etiology is expected to be congenital.
As other papers point out, a broad ligament hernia is difficult to diagnose solely by imaging tests. ${ }^{2,3}$ The radiological tests may show signs of small bowel obstruction. In some cases, the computed tomography may even suggest an internal hernia as the cause of the bowel obstruction. Nevertheless, it is extremely difficult to identify a broad ligament defect with such tests..$^{2,3}$ It comes as no surprise that in the three reported cases the imaging tests suggested bowel obstruction and internal hernia, but none identified the broad ligament defect.

The treatment for broad ligament hernia is always surgical and should be performed as soon as possible in order to reduce the chances of intestinal necrosis. The herniated loops should be reduced and, if necrotic, resected. To prevent recurrence, the broad ligament should be completely divided or its defect closed (by suture or clips). ${ }^{1,3,4}$ The literature reports some broad ligament hernias successfully treated by laparoscopic surgery. ${ }^{5-7}$ In the three cases presented in this study, the surgical team opted for a laparotomic approach since all patients had a noticeable distension of the majority of the small intestine. Loop distension increases the risk of complications associated with laparoscopic surgery due to reduced peritoneal free space. Moreover, the intestine affected by the distension becomes more fragile. Altogether, these factors increase the risk of iatrogenic
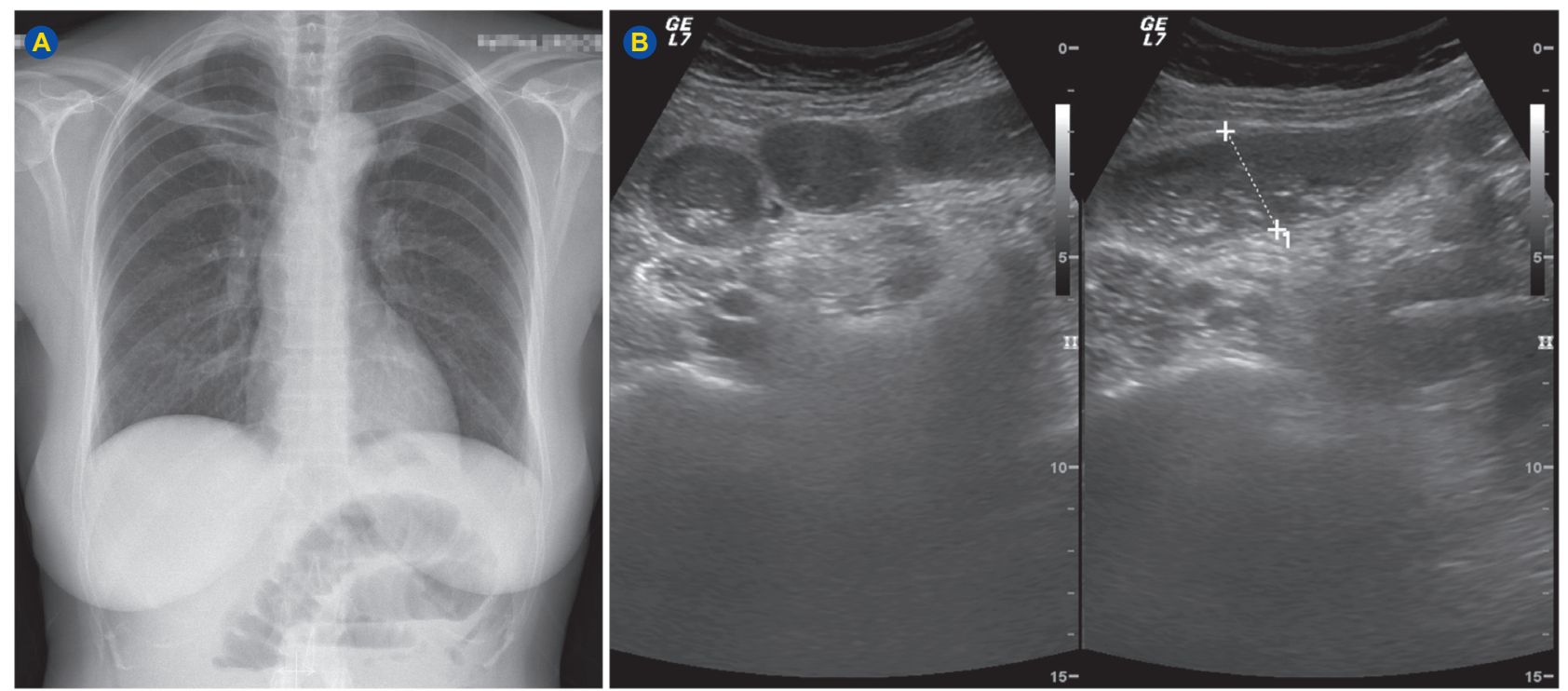

Figure 4 - Thoracic radiography with distended intestinal loops on the upper abdomen (A); Abdominal echography with distended intestinal loops and slight amount of inter-loops liquid (B). 
intestinal perforation. ${ }^{3}$

This paper intends to raise awareness regarding the broad ligament hernia as a differential diagnosis of bowel obstruction in middle-age women with no surgical history. An early diagnosis is extremely important since it enables a prompt surgical repair that reduces the morbidity and mortality associated with bowel strangulation.

\section{PROTECTION OF HUMANS AND ANIMALS}

The authors declare that the procedures were followed according to the regulations established by the Clinical Research and Ethics Committee and to the Helsinki Declaration of the World Medical Association.

\section{REFERENCES}

1. Agresta F, Michelet I, Candiotto E, Bedin N. Incarcerated internal hernia of the small intestine through a breach of the broad ligament: two cases and a literature review. JSLS. 2007;11:255-7.

2. Hiraiwa K, Morozumi K, Miyazaki H, Sotome K, Furukawa A, Nakamaru M. Strangulated hernia through a defect of the broad ligament and mobile cecum: a case report. World J Gastroenterol. 2006;12:1479-80.

3. Varela GG, López-Loredo A, García León JF. Broad ligament herniaassociated bowel obstruction. JSLS. 2007;11:127-30.

4. Karmali S, Zurawin RK, Sherman V. Herniation through the broad ligament. CMAJ. 2010;182:174.

\section{DATA CONFIDENTIALITY}

The authors declare having followed the protocols in use at their working center regarding patients' data publication.

\section{PATIENT CONSENT}

Obtained.

\section{CONFLICTS OF INTEREST}

All authors report no conflict of interest.

\section{FUNDING SOURCES}

This research received no specific grant from any funding agency in the public, commercial, or not-for-profit sectors.

5. Toolabi K, Zamanian A, Parsaei R. Bowel obstruction caused by broad ligament hernia successfully repaired by laparoscopy. Ann R Coll Surg Engl. 2018;100:94-6.

6. Garcia-Oria M, Inglada J, Domingo J, Biescas J, Ching C. Small bowel obstruction due to broad ligament hernia successfully treated by laparoscopy. J Laparoendosc Adv Surg Tech A. 2007;17:666-8.

7. Matsunami M, Kusanagi H, Hayashi K, Yamada S, Kano N. Broad ligament hernia successfully treated by laparoscopy: Case report and review of literature. Asian J Endosc Surg. 2014;7:327-9. 